Paweł Śpica ${ }^{1}$

Uniwersytet Gdański

ORCID: 0000-0002-0170-9834

\title{
WYCHOWANIE MORALNE W ŚWIETLE „ROZPRAW OBYCZAJOWYCH” PUBLIKOWANYCH NA ŁAMACH „KATOLIKA DYECEZYI CHEŁMIŃSKIEJ” W LATACH 1849-1850
}

Moral Education in the light of "Moral Dissertations" Published in the Pages of "Katolik Dyecezyi Chełmińskiej" in the Years 1849-1850

Summary: Since ancient times morality has been the subject of reflection by philosophers and theologians of various religions. Religious education is closely related to moral education. From the beginning, ethical issues has also occupied an important place in the teaching of the Catholic Church. In the $17^{\text {th }}$ and $18^{\text {th }}$ centuries, moral problems were described in particular by authors of moral theology textbooks. Along with the development of the nineteenth-century periodicals, the issues of moral education were also addressed in Polish newspapers. One of them was the "Katolik Dyecezyi Chełmińskiej". This newspaper was published in West Prussia in 1849-1851. In this magazine were published, among others, "moral dissertations", aimed at spreading moral attitudes and behavior in accordance with the teaching of the Catholic Church. A purpose of the article is a (re)construction of moral education in the light of these dissertations, as well as to clarify: who they were addressed to, what they were to serve and what moral ideas they tried to expand.

Keywords: moral education, ethics, moral theology, Polish press, West Prussia

${ }^{1}$ Dr Paweł Śpica - adiunkt w Zakładzie Historii Nauki, Oświaty i Wychowania w Instytucie Pedagogiki na Wydziale Nauk Społecznych Uniwersytetu Gdańskiego. Adres: Instytut Pedagogiki Uniwersytetu Gdańskiego, ul. Jana Bażyńskiego 4, 80-309 Gdańsk; e-mail: pawel.spica@ug.edu.pl. 


\section{Wprowadzenie}

Mnogość prezentowanych stanowisk sprawia, że nie istnieje jedna określona definicja wychowania moralnego. Niemniej, najogólniej rzecz ujmując, pojęcie to można rozumieć jako „oddziaływanie na osobowość wychowanka, aby umiał on odróżniać dobro od zła i aby wybierał dobro, a odrzucał zło. Związane jest z przyjęciem i zaakceptowaniem określonych norm postępowania"2. W zależności od wyznawanego światopoglądu i podstaw ideologicznych różnie też formułowane są cele wychowania moralnego. Mieczysław Łobocki, wychodząc z perspektywy pedagogicznej, wskazuje, że wychowanie to służy „przyswajaniu wiedzy o problemach moralnych i umiejętności odróżniania tego, co moralnie dobre i godziwe, od tego, co złe, niegodziwe czy wręcz nikczemne z moralnego punktu widzenia”’3. Sam zaś rozwój moralny następuje w trzech sferach, tj.: poznawczej (poprzez uświadomienie sobie tego, co dobre, a co złe), emocjonalnej (poprzez rozwijanie wrażliwości moralnej) i behawioralnej (poprzez konkretne postępowanie moralne). Jak wynika z powyższych definicji, w wychowaniu moralnym szczególnie istotna jest nauka odróżniania postaw i zachowań pojmowanych w kategoriach dobra i zła ${ }^{4}$.

Od najdawniejszych czasów kwestie etyczne stanowiły przedmiot rozważań filozofów i teologów. Wychowanie moralne zajmuje bowiem ważne miejsce zarówno $\mathrm{w}$ światopoglądzie laickim, jak i zbudowanym na podstawie religii ${ }^{5}$. Pozostając w ścisłym związku z wychowaniem religijnym, problematyka moralna od samego początku odgrywała też istotną rolę w nauczaniu Kościoła katolickiego. Znajdowała ona szczególne miejsce w pracach z zakresu teologii moralnej.

Z uwagi na podjętą tematykę warto pokrótce przybliżyć historyczny rozwój wspomnianej dyscypliny. Ksiądz Franciszek Greniuk wyróżnił kilka etapów w jej dziejach. Pierwszy, przypadający na okres patrystyczny, określany jest mianem indeterminacji. Sprowadzał się on do wyjaśniania aktualnych problemów moralnych poruszanych w wypowiedziach o charakterze homiletycznym. Etap drugi scholastyczny - (na podstawie tradycji arystotelesowsko-tomistycznej) cechował się pojmowaniem moralności jako nauki o cnocie (sprawności). Etap trzeci, który rozwinął się w XVII wieku, znamionowało natomiast sprowadzanie teologii moralnej do nauki o grzechu i granicach tego, co jest dozwolone. Jak wskazuje ks. Greniuk,

${ }^{2}$ Stanisław Jasionek, Wychowanie moralne (Kraków: WSF-P Ignatianum, Wydawnictwo WAM 2004), 12.

${ }^{3}$ Mieczysław Łobocki, Wychowanie moralne w zarysie (Kraków: Oficyna Wydawnicza „Impuls" 2009), 14.

${ }^{4}$ Tamże.

${ }^{5}$ Jasionek, Wychowanie..., 11. 
[...] w tym ostatnim okresie teologia moralna ma więc charakter wyraźnie legalistyczny i minimalistyczny, a zarazem zdecydowanie kazuistyczny. Teologowie moraliści w zasadzie tylko rozwiązywali różne przypadki sumienia, aby dostarczyć spowiednikom gotowe wzory do ich rozstrzygania w konfesjonale. Usiłowano wprawdzie drogą opracowań z zakresu teologii ogólnej poddawać pewne zasady moralne stałej refleksji, ale ta teoretyczna praca nie zdołała przezwyciężyć w całości kanonistycznie zbudowanej struktury. Stale tylko, mniej lub więcej udolnie, kierowano uwagę na zagadnienia praktyczne ${ }^{6}$.

Takie podejście do teologii moralnej znalazło swoje odzwierciedlenie w popularnym w Europie i w Polsce w XVII i XVIII wieku podręczniku Hermanna Busenbauma pt. Medulla theologiae moralis, który po raz pierwszy został wydany w 1645 roku (zaś w Polsce dziesięć lat później). Z perspektywy badanej problematyki istotne jest wskazanie, że w pracy tej podstawę rozróżnienia gatunków grzechów stanowią nie cnoty, którym grzechy te się sprzeciwiają, lecz formalnie różne przykazania. Takie praktyczne podejście do teologii moralnej, wyłączające zagadnienia ogólne, cechowało także osiemnastowieczne pisarstwo św. Alfonsa Marii Liguoriego, określanego mianem księcia moralistów, który wywarł znaczący wpływ na dzieje omawianej dyscypliny ${ }^{7}$.

Początek nowej epoki w dziejach teologii moralnej wyznaczyła rewolucja francuska i jej następstwa. Jak zauważa ks. Greniuk, wydarzenie to w zasadniczy sposób wpłynęło bowiem na zmianę warunków ówczesnego życia umysłowego i moralnego. Dla dalszego rozwoju teologii moralnej nie bez znaczenia pozostawały też przemiany ustrojów społecznych, które dokonywały się w wielu krajach Europy, m.in. pod wpływem wojen napoleońskich. Na ziemiach polskich początek nowej epoki wiązał się z kolei z rozbiorami, wskutek których Polacy utracili możliwość prowadzenia własnej i niezawisłej polityki kulturalnej i naukowej, także w zakresie kształcenia duchownych ${ }^{8}$.

Niewątpliwie istotny wpływ na rozwój teologii moralnej, choć z pewnym opóźnieniem, wywarło także oświecenie. W XVIII wieku moraliści katoliccy niechętnie bowiem podejmowali dialog z lansowanymi przez filozofów oświecenia ideami racjonalizmu, naturalizmu i nowym pojmowaniem człowieka. Inny czynnik, mający znaczenie dla przemian w zakresie teologii moralnej, stanowiła też kasata zakonu jezuitów, odgrywających ważną rolę w kształceniu duchownych.

${ }^{6}$ Franciszek Greniuk, „Teologia moralna w XIX wieku”, w: Dzieje teologii katolickiej w Polsce, t. 3: Wiek XIX i XX, cz. 1, red. Marian Rechowicz (Lublin: Wydawnictwo Towarzystwa Naukowego Katolickiego Uniwersytetu Lubelskiego 1976), 223.

7 Tamże, 223-224; zob. Franciszek Greniuk, Katolicka teologia moralna w poszukiwaniu własnej tożsamości (Lublin: Redakcja Wydawnictw Katolickiego Uniwersytetu Lubelskiego 1993), 66-69; por. Servais Théodore Pinckaers, Źródła moralności chrześcijańskiej. Jej metoda, treść, historia (Poznań: W Drodze 1994), 243-259.

${ }^{8}$ Greniuk, „Teologia...”, 225. 
Ich miejsce w tym zakresie w dużej mierze zajęli księża misjonarze, których centrala znajdowała się we Francji ${ }^{9}$.

Na ziemiach dawnej Rzeczypospolitej panująca w XIX wieku sytuacja polityczna nie sprzyjała rozwojowi polskiej teologii moralnej. Do tego stanu rzeczy przyczyniło się także obniżenie poziomu tej dyscypliny, które nastąpiło we wcześniejszym okresie, choć warto odnotować, że w drugiej połowie XVIII wieku pojawiły się próby ożywienia polskiej moralistyki, czego świadectwo stanowi program Komisji Edukacji Narodowej, m.in. zakładający reformę nauczania zasad moralności. Niemniej w pierwszej połowie XIX wieku w podejściu do teologii moralnej dominował pewien legalizm i minimalizm, co przekładało się na tworzone wówczas dzieła. Ówcześni moraliści skupiali się głównie na kwestiach takich jak: prawa, grzechy i sakramenty. Nie rozwijali natomiast nie tylko problematyki cnót moralnych, ale i teologicznych oraz cnoty religijności ${ }^{10}$. W rezultacie w ówczesnym podejściu duchownych do wychowania moralnego pokutowała wspomniana etyka legalistyczna i minimalistyczna zarazem ${ }^{11}$.

\section{Rola i miejsce „Katolika Dyecezyi Chełmińskiej” w czasopiśmiennictwie Prus Zachodnich}

Wraz z rozwojem XIX-wiecznego czasopiśmiennictwa rozprawy o tematyce moralnej zaczęto wydawać nie tylko $\mathrm{w}$ formie dzieł podręcznikowych i spowiedniczych, jak to miało miejsce w okresie poprzedzającym, ale także w postaci artykułów publikowanych na łamach prasy ${ }^{12}$. W ten sposób treści z zakresu wychowania moralnego, odpowiednio dostosowane do poziomu intelektualnego czytelników, do których adresowane było dane pismo, znajdowały szersze grono odbiorców. Do tego stanu rzeczy przyczynił się także postępujący proces alfabetyzacji.

W okresie zaborów na łamach polskiej prasy treści o tematyce moralnej często koegzystowały z tematyką narodową i religijną. Podtrzymanie i rozwijanie tożsamości polskiej stanowiło bowiem priorytet dla wielu polskich redaktorów i wydawców. Działo się tak zwłaszcza na terenie ówczesnej prowincji Prusy Zachodnie, gdzie patriotyczna prasa, $\mathrm{z}$ reguły o charakterze konserwatywno-ludowym, pełniła istotną funkcję polityczną, w pewien sposób zastępując brak organizacji i struktur partyjnych. Wychodząc z perspektywy pedagogicznej, można powiedzieć, że głównym celem polskich gazet $\mathrm{w}$ Prusach Zachodnich w XIX i w początkach XX wieku było wychowanie patriotyczne, nierozdzielnie związane $\mathrm{z}$ edukacją religijną, których istotną składową zawsze stanowiły kwestie moralno-obyczajowe.

\footnotetext{
9 Tamże, 225-226.

${ }^{10}$ Jan Pryszmont, Historia teologii moralnej (Warszawa: Akademia Teologii Katolickiej 1987), 356.

11 Por. Greniuk, „Teologia..., 245.

${ }^{12}$ Pryszmont, Historia..., 357.
} 
We wspomnianym regionie początki rozwoju polskiego czasopiśmiennictwa sięgają okresu Wiosny Ludów. W Prusach w 1848 roku została bowiem zniesiona cenzura prewencyjna oraz system koncesyjny, które stanowiły poważne przeszkody na drodze rozwoju prasy. Nowe prawo, likwidując dotychczasowe bariery legislacyjne, umożliwiło wydawanie pierwszych polskich pism politycznych ${ }^{13}$. W samych Prusach Zachodnich w połowie XIX wieku główny ośrodek polskiego czasopiśmiennictwa stanowiło Chełmno ${ }^{14}$. Tam też ukazywała się „Szkółka Narodowa” (przekształcona następnie w „Szkołę Narodową"). Czasopismo to wychodziło od lipca 1848 do końca czerwca 1850 roku. Z kolei w październiku 1848 roku został założony „Biedaczek, czyli Mały i Tani Tygodnik dla Biednego Ludu", początkowo drukowany w Toruniu, a następnie w Chełmży. Pismo to również upadło z końcem czerwca 1850 roku $^{15}$.

Krótki żywot pierwszych polskich czasopism Prus Zachodnich nie był przypadkowy. Bezpośrednią przyczyną upadku „Szkoły Narodowej” i „Biedaczka” był zakaz ich kolportażu przez pocztę, który został wydany przez władze rejencji kwidzyńskiej. Podstawę prawną tego zakazu stanowiła ustawa prasowa z czerwca 1850 roku, która pozwalała na odmowę debitu pocztowego. Uchwalenie tej ustawy wynikało z odejścia rządu pruskiego od liberalnego kursu obranego w okresie Wiosny Ludów. W praktyce odmowa kolportażu danego pisma przez pocztę była jednoznaczna z zakazem jego wydawania, ponieważ dzięki abonamentom pocztowym możliwe było rozsyłanie prasy do małych miasteczek i wsi, gdzie mieszkała największa grupa odbiorców polskich gazet w Prusach Zachodnich. Zasadniczą przyczyną odmowy kolportażu "Szkoły Narodowej” i „Biedaczka” było uznanie ich za pisma szkodliwe z punktu widzenia interesów państwa ${ }^{16}$.

Upadek wspomnianej prasy sprawił, że przez kilka miesięcy jedyną polską gazetę na terenie Prus Zachodnich stanowił tytułowy „Katolik Dyecezyi Chełmińskiej”. Pismo to w formie tygodnika ukazywało się w Chełmnie od 4 lipca 1849 roku. Jego wydawcą był znany chełmiński drukarz Józef Gółkowski ${ }^{17}$. Początkowo redaktorem „Katolika” był ks. Adam Pokojski ${ }^{18}$, proboszcz w Kijewie

${ }^{13}$ Jacek Banach, Prasa polska Prus Zachodnich w latach 1848-1914 (Gdańsk: Wydawnictwo Uniwersytetu Gdańskiego 1999), 19; Tadeusz Cieślak, Prasa Pomorza Wschodniego w XIX i XX wieku (Warszawa: Państwowe Wydawnictwo Naukowe 1966), 32; Andrzej Romanow, „Pielgrzym” pelpliński w latach 1869-1920 (Gdańsk-Pelplin: Instytut Kaszubski 2007), 17-19.

${ }_{14}$ Zob. Szczepan Wierzchosławski, „Od upadku Polski do odzyskania niepodległości (17951920)", w: Dzieje Chetmna. Zarys monograficzny, red. Marian Biskup (Warszawa-Poznań-Toruń: Państwowe Wydawnictwo Naukowe 1987), 235-250.

${ }^{15}$ Banach, Prasa..., 37-40.

16 Tamże, 38-41.

17 Andrzej Bukowski, „Gółkowski Józef Szczepan”, w: Słownik biograficzny Pomorza Nadwiślańskiego, t. 2: G-K, red. Zbigniew Nowak (Gdańsk: Wydawnictwo Gdańskie 1994), 89-90.

${ }_{18}$ Zdzisław Mrozek, „Pokojski Adam”, w: Słownik..., red. Stanisław Gierszewski, t. 3: $L-P$, red. Zbigniew Nowak (Gdańsk: Wydawnictwo Gdańskie 1997), 452-453. 
pod Chełmnem, zaś po jego śmierci - ks. Kazimierz Kręcki ${ }^{19}$, proboszcz w Starogrodzie pod Chełmnem. W numerze 11 z 12 września 1849 roku ks. Kręcki zapewniał, że będzie kontynuował program nakreślony przez swojego poprzednika ${ }^{20}$.

Jak wskazuje Jacek Banach, „Katolik Dyecezyi Chełmińskiej”

[...] z polskich tytułów prasowych ukazujących się w Chełmnie najsilniej akcentował swoje przywiązanie do Kościoła katolickiego i religii [...]. Pismo to poświęcone było umacnianiu zasad wiary, ale jednocześnie nie zaniedbywało problematyki językowej. Opublikowane powiastki religijne zwykle wiązały się z przypominaniem polskich tradycji narodowych. Popularyzowano żywoty świętych polskich oraz zwyczaje religijne, zachowane wśród ludu polskiego ${ }^{21}$.

Na łamach „Katolika” pisano wiele na temat diecezji chełmińskiej (która zajmowała większą część Prus Zachodnich). Silnie podkreślano też zależności między religią a narodowościąa ${ }^{22}$ Tematyka publikowanych tekstów oscylowała nie tylko wokół zagadnień religijnych, ale koncentrowała się także na sprawach historycznych, społeczno-obyczajowych i informacyjnych.

W 1849 i 1850 roku układ gazety był bardzo podobny. W 1849 roku „Katolik Dyecezyi Chełmińskiej” zawierał: „rozprawy religijne”, „rozprawy obyczajowe”, „rozprawy historyczne”, „rozprawy diecezjalne”, „rozprawy treści rozmaitej”, „życiopisy”23, „wiadomości kościelne”, „wiadomości osobiste”, „uwiadomienia i prośby” ${ }^{24}$. W 1850 roku redakcja zrezygnowała $\mathrm{z}$ "rozpraw diecezjalnych” i „życiopisów”, wprowadziła zaś dział noszący nazwę: „początek założenia niektórych sławnych miast i wsi w Prusiech i ich dawniejsze dzieje" 25 . Z kolei w 1851 roku na łamach „Katolika” publikowano: „życiopisy biskupów chełmińskich”, „rozprawy treści rozmaitej”, „znaczenie Ewangelii”, „wiadomości o założeniu i dziejach niektórych znaczniejszych miast i wsi w Prusiech" oraz „uwiadomienia”26.

„Katolik Dyecezyi Chełmińskiej” upadł we wrześniu 1851 roku. Jego krótki żywot był związany m.in. ze wspomnianymi już, niekorzystnymi dla rozwoju prasy polskiej rozwiązaniami prawnymi i trudnościami finansowymi ${ }^{27}$. Za Jackiem Banachem warto podkreślić, że:

19 Anastazy Nadolny, „Kręcki Kazimierz”, w: Słownik..., t. 2, 507.

${ }^{20}$ Banach, Prasa..., 39.

${ }^{21}$ Tamże, 48.

${ }^{22}$ Katolik Dyecezyi Chetmińskiej (dalej cyt.: KDCh), nr 7, 15.08.1849.

${ }^{23}$ Pisownia oryginalna.

${ }^{24} \mathrm{KDCh}, \mathrm{nr} 1,1.07 .1849$.

25 Tamże, nr 1, 2.01.1850.

26 Tamże, nr 1, 1.01.1851.

27 Banach, Prasa..., 39. 
„Katolik Diecezji Chełmińskiej” ukazywał się w najtrudniejszym dla rozwoju prasy okresie, nie mógł więc się rozwinąć w pismo polityczne, ponieważ od połowy $1850 \mathrm{r}$. nie mogły się ukazywać w państwie pruskim żadne pisma opozycyjne wobec rządu. Do jesieni 1850 r. „Katolik” był zupełnie odosobnionym przypadkiem pisma polskiego wydawanego w Prusach Zachodnich ${ }^{28}$.

\section{Przedmiot i cel badań}

Andrzej Romanow wskazuje, że „prasoznawcę, w tym historyka prasy, interesuje prasa jako taka, natomiast historyka przede wszystkim informacja zawarta w prasie" 29 . Próbując przeszczepić powyższe twierdzenie na grunt metodologii badań historyczno-oświatowych, należy podkreślić, że historyk wychowania, z racji swych pedagogicznych zapatrywań, zasadniczo koncentruje uwagę wokół treści materiału prasowego, niejednokrotnie stanowiącego przedmiot podejmowanych przez niego analiz. Nie inaczej jest w przypadku niniejszych badań, których przedmiot stanowią treści publikowanych na łamach „Katolika Dyecezyi Chełmińskiej” „rozpraw obyczajowych”.

Andrzej Notkowski zwraca uwagę, że: „[...] prasą jako źródłem historycznym posługiwać się można w dwóch celach: 1. rekonstrukcji wydarzeń, której dokonujemy na podstawie wypowiedzi informacyjnych, tj. relacjonujących fakty; 2. odtworzenia funkcjonujących wśród ludzi w danym czasie idei, wzorców i wartości, czyli badania świadomości społecznej” ${ }^{30}$. W przypadku podjętej problematyki drugi ze wskazanych przez Notkowskiego celów wydaje się szczególnie istotny. Cel główny niniejszego artykułu stanowi bowiem (re)konstrukcja wychowania moralnego w świetle „rozpraw obyczajowych” publikowanych na łamach „Katolika Dyecezyi Chełmińskiej” i odpowiedź na następujące pytania badawcze: Do kogo były skierowane „rozprawy obyczajowe”? Czemu miały służyć? Jakie idee moralne próbowano za ich pomocą rozszerzać?

Choć niniejszy artykuł został napisany z perspektywy historyczno-pedagogicznej, należy podkreślić, że niemożliwe było dokonanie analizy zebranego materiału badawczego pod kątem wychowania moralnego w oderwaniu od jego teologicznego kontekstu. W związku z czym publikacja ta ma charakter interdyscyplinarny.

28 Tamże, 48.

29 Andrzej Romanow, „Prasa jako źródło do dziejów Pomorza XIX wieku”, w: Prasa regionalna jako źródło do badań historycznych okresu XIX i XX wieku, red. Joanna Nowosielska-Sobel, Grzegorz Strauchold, Tomasz Ślepowroński (Wrocław: ATUT 2011), 12.

30 Cyt. za: tamże. 


\section{Cele i treści „rozpraw obyczajowych”}

„Rozprawy obyczajowe” były publikowane w latach 1849-1850 i stanowiły wówczas jedną ze stałych części „Katolika Dyecezyi Chełmińskiej”. Wprawdzie nie ukazywały się w każdym jego numerze, niemniej stanowiły istotną składową pisma. Autorzy rozpraw nie są znani z nazwiska. Jeśli podpisywali się pod danym artykułem, to używali wyłącznie inicjałów. Stąd możemy jedynie przypuszczać, że najprawdopodobniej spora część rozpraw wyszła spod pióra ks. Mateusza Osmańskiego, proboszcza w Brodnicy, tłumacza i autora pism o tematyce religijnej i powieści ludowych ${ }^{31}$. Na autorstwo ks. Osmańskiego wskazują inicjały: „M.O.” i „K.M.O.”2.

„Rozprawy obyczajowe” składały się z kilkudziesięciu spójnych ze sobą artykułów. Nie były to teksty przypadkowe. Na początku każdego roku redakcja „Katolika” publikowała ich tytuły wraz z numeracją stron. W 1849 roku „rozprawy obyczajowe" tworzyło szesnaście artykułów, tj.: O samolubstwie, O pysze, Wychowanie dziatek, O łakomstwie, Oszczędność, Komunizm, O rozrzutności, Przyjaźń, O nieczystości, O źródłach nieczystości i lekarstwach przeciw niej, O gniewie, O przeklęctwie, O łagodności, Stan opłakania godny pijanicy przez niego samego skreślony, Czy stan duchowny tego, który mu się poświęcił wyklucza od udziału $w$ polityce i $w$ patriotyzmie narodowym?, Kilka słów o związku małżeńskim ${ }^{33}$. W 1850 roku rozpraw takich ukazało się pięć, przy czym niektóre z nich składały się z kilku części. Należały do nich następujące teksty: $O$ zazdrości, O potrzebie zaprowadzenia towarzystw wstrzemięźliwości i połaczenia onegoż z bractwami religijnemi, O obżarstwie, Dawniej a teraz i O niewstrzemięźliwości w piciu gorących napojów. Ostatni z wymienionych artykułów był zdecydowanie najbardziej obszerny i został opublikowany w sześciu częściach ${ }^{34}$.

Można wnioskować, że „rozprawy obyczajowe” w pierwszym rzędzie miały na celu kształtowanie postaw i zachowań moralnych wśród ludności polskiej Prus Zachodnich. Przytaczane w poszczególnych tekstach przykłady niewłaściwego postępowania odnoszono do przedstawicieli różnych warstw społecznych ${ }^{35}$. Generalnie rzecz ujmując, narracja rozpraw zbudowana była na nauczaniu o siedmiu grzechach głównych. Najczęściej punktem wyjścia do dalszych rozważań czyniono ludzkie wady i przywary. Każdy artykuł, poprzez który „Katolik” podejmował próbę oddziaływania moralnego na swoich odbiorców, siłą rzeczy był

${ }^{31}$ Henryk Mross, „Osmański Mateusz”, w: Słownik..., t. 3, 365-366.

${ }^{32}$ Ksiądz Osmański był najprawdopodobniej autorem tekstów: O samolubstwie, O pysze, O łakomstwie, Oszczędność, O rozrzutności, O nieczystości, O źródłach nieczystości i lekarstwach przeciw niej, O zazdrości, O niewstrzemięźliwości. Być może jego autorstwa jest także kilka innych niepodpisanych artykułów.

${ }^{33} \mathrm{KDCh}, \mathrm{nr} 1,1.07 .1849$.

34 Tamże, nr 1, 2.01.1850.

35 Tamże, nr 15, 10.10.1849; tamże, nr 19, 7.11.1849; tamże, nr 5, 30.01.1850. 
więc przesiąknięty treściami religijnymi. Stąd mimo że pismo zawierało odrębne działy poświęcone sprawom wiary, „rozprawy obyczajowe” jednocześnie służyły wychowaniu moralnemu i religijnemu.

Jednym z zadań rozpraw było też wzbudzenie w czytelnikach refleksji moralnej nad własnym myśleniem i postępowaniem oraz rozwój samoświadomości. Autorzy omawianych tekstów krytykowali powierzchowność ludzkich zachowań, wskazywali, że wiele czynów uchodzących za dobre podszytych jest złą intencją ${ }^{36}$.

Charakterystykę treści wychowania moralnego w świetle „rozpraw obyczajowych" należy rozpocząć od odniesienia się do pierwszego artykułu rozpoczynającego tę problematykę, który nosi wymowny tytuł: O samolubstwie. Jego autor korzenia grzechu, a w konsekwencji zepsucia moralnego, charakteryzującego współczesne mu społeczeństwo, upatruje w ludzkim egoizmie, wyrosłym na źle pojętej miłości własnej, nieproporcjonalnie rozbudowanej, przysłaniającej miłość Boga i bliźniego ${ }^{37}$. Autor ten stwierdza jednocześnie, że jednostki, które najbardziej owładnięte są egoizmem, z reguły nie potrafią obiektywnie ocenić samych siebie. Często zdaje się, że czynią dobro, gdy tymczasem dbają przede wszystkim o swój własny interes. Ponadto ich wykoślawiony i zbyt optymistyczny obraz własnej osoby nie pozwala im na zobaczenie popełnianych przez siebie błędów ${ }^{38}$.

W podobny sposób „Katolik” pisał o relacjach międzyludzkich, którym poświęcił zresztą sporo miejsca. Problematykę tę odnajdujemy m.in. w tekstach poruszających zagadnienia takie jak: gniew ${ }^{39}$, przyjaźn ${ }^{40}$, zazdrośćc ${ }^{41}$, nieczystość $^{42}$ czy niewstrzemięźliwośćc ${ }^{43}$. W artykule pt. O przyjaźni ganiono np. warstwę szlachecką za nazywanie przyjaciółmi dopiero co poznanych osób, których pochlebne słowa często nie oddawały rzeczywistości, chwalono zaś roztropność ludności chłopskiej, której zdrowy rozsądek nakazywał unikać stosowania określeń nierzetelnych czy fałszywych. Jednocześnie nauczano o konieczności budowania przyjaźni międzyludzkich opartych na miłości Bożej, gdyż: „miłość ludzka nieugruntowana na miłości Boga, jest tylko żądzą, namiętnością. Dlatego jest zmienną i nietrwałą" 4 .

W „rozprawach obyczajowych” ze wszystkich ludzkich przywar najwięcej miejsca poświęcono problemowi pijaństwa, najprawdopodobniej traktując go jako często występujący wśród ludności polskiej i dotkliwy w skutkach ${ }^{45}$.

\footnotetext{
36 Tamże, nr 3, 18.07.1849; tamże, nr 4, 25.07.1849.

37 Tamże.

38 Tamże, nr 4, 25.07.1849.

39 Tamże, nr 21, 21.11.1849.

40 Tamże, nr 19, 7.11.1849.

41 Tamże, nr 5, 30.01.1850; tamże, nr 6, 6.02.1850.

42 Tamże, nr 19, 7.11.1849.

43 Tamże, nr 24, 12.06.1850.

44 Tamże, nr 19, 7.11.1849.

45 Tamże, nr 24, 12.12.1849; tamże, nr 11, 13.03.1850; tamże, nr 22, 29.05.1850; tamże, nr 23, 5.06.1850; tamże, nr 24, 12.06.1850; tamże, nr 25, 19.06.1850; tamże, nr 26, 26.06.1850.
} 
Przy pomocy tekstów poruszających to zagadnienie próbowano oddziaływać na czytelnika, wskazując szereg negatywnych konsekwencji nadużywania alkoholu, zarówno tych indywidualnych, jak i społecznych. Przestrzegano też przed rozpijaniem dzieci i młodzieży, a także zwracano się z apelem do rodziców, by ci przykładali większą wagę do kontroli swojego potomstwa i pod żadnym pozorem nie częstowali go wódką ${ }^{46}$. Ponadto wskazywano też na panujące wśród Polaków przyzwolenie społeczne na pijaństwo, wciąganie w nie innych (w tym dzieci i młodzież) oraz określanie niepijących mianem „skąpców” czy „pobożnisiów”"47.

Kolejny istotny problem społeczny dotykający ludność polską, a poruszany $\mathrm{w}$ „rozprawach obyczajowych”, stanowiło nieumiejętne gospodarowanie dobrami materialnymi. Wpierw w artykule pt. O łakomstwie zwrócono uwagę na ludzką chciwość i skąpstwo, wynikające m.in. z troski o własną przyszłość ${ }^{48}$, następnie zaś w tekście pt. Oszczędność wskazano na drugą skrajność, a mianowicie na rozrzutność, której skutkiem była nędza wielu Polaków. Autor omawianego tekstu wśród ludności polskiej zauważał wiele przykładów braku oszczędności (np. mentalność wyższych warstw społecznych opierała się na przekonaniu, że w związku z posiadaniem wielu dóbr jej stan „zakazuje być liczykrupą”). Takie marnotrawienie było piętnowane na łamach „Katolika” i wskazywano, że nie ma ono nic wspólnego z ideą dobroczynności ${ }^{49}$. Z kolei w artykule pt. O łakomstwie próbowano wpłynąć na przeciwstawnych odbiorców, tj. ludzi skąpych, powołując się m.in. na ewangeliczną przypowieść o niemiłosiernym bogaczu i biednym Łazarzu. Przypomniano zatem, że tego pierwszego z uwagi na jego chciwość i skąpstwo spotkała surowa kara w postaci mąk piekielnych ${ }^{50}$. W „rozprawach obyczajowych” wyjaśniono też różnicę między chciwością a oszczędnością, wskazując na istniejącą między nimi cienką granicę:

[...] gdy chciwy zbiera, aby sam miał a nikomu nieudzielił, zbiera, bo zbiory kocha; oszczędny jest na to bacznym, żeby się nic z jego własności nie zmarnotrawiło, co może jeszcze być użytem, żeby nie zniszczało, a to z tej przyczyny, że u niego i drobnostka jest darem Boga, danym do użycia jemu i bliźniemu; że przeto zmarnotrawić ją byłoby naganną rozrzutnością i pogardą darów Najwyższego. Z tego powodu oszczędny nie czyni nigdy wydatków zbytecznych, to jest takich bez których się obejść można ${ }^{51}$.

Ponadto zwrócono uwagę na konieczność umiarkowania, które czyni oszczędnego dobrym gospodarzem, a nie wspomnianym „liczykrupą”. Człowiek oszczędny potrafi bowiem tak zarządzać swoim majątkiem, że jest w stanie zarówno zapewnić godne warunki życia swojej rodzinie, jak i dzielić się tym,

\footnotetext{
46 Tamże, nr 23, 5.06.1850; tamże, nr 25, 19.06.1850; tamże, nr 26, 26.06.1850.

47 Tamże, nr 22, 29.05.1850; tamże, nr 26, 26.06.1850.

48 Tamże, nr 11, 12.09.1849.

49 Tamże, $\mathrm{nr} 15,10.10 .1849$.

50 Tamże, nr 11, 12.09.1849.

51 Tamże, nr 15, 10.10.1849.
} 
co posiada, z potrzebującymi. Autor artykułu pt. Oszczędność w następujących słowach tłumaczył, w jaki sposób umiejętnie gospodarować posiadanymi zasobami: „Nie wydawaj nigdy więcej nad słuszną potrzebę, ochraniaj wszystkiego co posiadasz, nie marnotraw nic z tego, co jest twoją własnością, ani pozwalaj, żeby twoi podwładni trwonili, w ten sposób oszczędzisz wiele, i będziesz mógł dać zasiłek potrzebnemu" ${ }^{2}$. Istotną różnicę między człowiekiem chciwym a oszczędnym, na którą wskazano w omawianym tekście, stanowi również intencja. O ile bowiem chciwiec nie wydaje pieniędzy z uwagi na własny egoizm, oszczędny nie czyni tego ze względu na "cele wspaniałe”53.

Interesujące wnioski na temat kondycji moralnej ówczesnego społeczeństwa zawiera także rozprawa poświęcona problematyce zazdrości. W artykule tym zwrócono uwagę, że zazdrość dotyka tak samo bogatych, jak i biednych. Wyjaśniono też, jak ją w sobie rozpoznać oraz przedstawiono jej negatywne skutki. Tłumaczono, że:

[...] jeźli ci niemiło patrzeć na cudze szczęście, - jeźli na pochwały milczysz smutny, lub usiłujesz one wycieńczyć, - jeźli czujesz w sobie jakiś wstręt od tej osoby, unikasz jej towarzystwa, - jeźli jesteś tak usposobionym, iżbyś chętnie widział człowieka tego nieszczęśliwym, pogardzonym, - jeźli do tego przyczyniasz się; - bądź pewnym, że tobą rządzi zazdrośśc ${ }^{4}$.

Autor cytowanego fragmentu wskazywał, że niegodziwe są nie tylko czyny wynikające z zazdrości, ale już same myśli, ponieważ szybko i w niepostrzeżony sposób mogą się one przerodzić „w kąkol”, tj. niegodziwe zachowania ${ }^{55}$. Poza tym z zazdrości wypływają niesłuszne oceny, jak posądzanie osoby, która dorobiła się majątku, o nieuczciwośćc ${ }^{56}$. Jednocześnie wspomniany autor zwrócił uwagę na ludzką nieżyczliwość w obliczu cudzego nieszczęścia. Przestrzegał też, że ludzie zazdrośni nie osiągną życia wiecznego. Postulował zatem, by zamiast usprawiedliwiać, uznać własną słabość i uczyć się postępowania według następujących zasad:

1. Rozważaj jak zazdrość jest brzydkim występkiem, narusza winne Bogu uszanowanie, bo jego rozporządzeniom przygania; - niema iskierki nawet miłości bliźnich; - jest okrutna dla samegoż zazdrośnika, bo mu nadarza zmartwienia.

2. Ucz się gardzić dobrami doczesnemi, na które jesteś chciwym, boć właśnie dlatego bolejesz, że je za nadto cenisz, a je inni posiadają! Im będziesz one więcej pogardzał, tem mniej będziesz zazdrościł.

\footnotetext{
52 Tamże.

53 Tamże.

${ }^{54}$ Tamże, nr 5, 30.01.1850.

55 Tamże.

56 Tamże, nr 6, 6.02.1850.
} 
3. Lecz tę chorobę przeciwnemi lekarstwami. Czujesz odrazę ku pewnej osobie, przeto że ma się lepiej od ciebie, przezwycięż się, obcuj z nią jak z bratem twoim. Uczujesz niesmak, gdy kogoś chwalą, przezwycięż się, chwal go wspólnie z drugimi. Kole cię w oczy cudza pomyślność, przezwycięż się, bądź mu na usługi, proś Boga o jego pomyślność. Gdy ci kolec ostu wlezie w ciało, dobyć go koniecznie trzeba, a chociażby przyszło i wyrżnąć go z ciała, inaczej będzie zawsze dokuczał.

4. Proś Boga, aby ci łaskawie dopomógł, do pozbycia się tej szkaradnej przywary ${ }^{57}$.

W „rozprawach obyczajowych” niejednokrotnie odnoszono się także do kwestii wychowania dzieci, w tym do powinności rodziców, do których apelowano, aby pod żadnym względem nie gorszyli swojego potomstwa, nie krzywdzili go, lecz najtroskliwiej nad nim czuwali ${ }^{58}$. W rozważaniach czynionych na łamach „Katolika” swoje miejsce znalazła też kwestia etyki seksualnej. W dwóch tekstach poświęconych tematyce nieczystości zwrócono uwagę na społeczne i indywidualne konsekwencje niemoralnych zachowań seksualnych. Przypomniano, że katolik powinien panować rozumem nad własną popędliwością i postępować zgodnie z Bożym przeznaczeniem. Ponadto wskazano na zewnętrzną i wewnętrzną stronę nieczystości, tj. na akt fizyczny i grzech popełniony myślą. Jednocześnie wyjaśniono, że szerząca się w XIX wieku niemoralność seksualna stanowiła skutek procesu laicyzacji, dokonującej się w Europie pod wpływem poglądów filozofów, takich jak Wolter czy Hegel ${ }^{59}$. Tymczasem autor tekstu $O$ źródłach nieczystości i lekarstwach przeciw niej religię postrzegał za najlepszą obronę przed uleganiem namiętnościom. Nawoływał też rodziców do unikania nieskromnych rozmów i czynów w obecności dzieci oraz nakazywał chronić je przed niewłaściwym towarzystwem. Ponadto zwracał uwagę na lekkomyślność młodych ludzi, stąd postulował baczniejszy nad nimi dozór i sprawowanie kontroli nawet po opuszczeniu przez nich domu rodzinnego. Do innych przyczyn nieczystości autor ten zaliczył m.in. czytanie nieodpowiednich książek (np. popularnych romansów), nietrzeźwość, obżarstwo i próżnowanie. Samą młodzież zachęcał zaś do słuchania rodziców, życia w skromności i poszukiwania wsparcia u Boga. Ponadto dziewczętom jako wzór stawiał Najświętszą Maryję Pannę ${ }^{60}$.

\footnotetext{
7 Tamże.

58 Tamże, nr 9, 29.08.1849.

59 Tamże, nr 19, 7.11.1849; tamże, nr 20, 14.11.1849.

60 Tamże, nr 20, 14.11.1849.
} 


\section{Obraz Boga w świetle „rozpraw obyczajowych” a wychowanie moralne}

Dla podjętej w niniejszej pracy tematyki nie bez znaczenia pozostaje kreowany w „rozprawach obyczajowych” obraz Boga. Istnieje bowiem ścisły związek między tym, jak dana jednostka pojmuje Boga, a jej rozumowaniem moralnym. W badanych tekstach Bóg Ojciec w pierwszej kolejności jawi się jako sprawiedliwy Sędzia. Autorzy rozpraw wskazują wprawdzie także na Jego miłosierdzie, niemniej sytuują je na nieco dalszym planie. Z kolei Jezus został przedstawiony jako doskonały przykład i wzorzec postępowania moralnego, a jednocześnie jako twórca prawa, którym powinni kierować się chrześcijanie. Stąd w poszczególnych artykułach Jezus określany jest mianem Prawodawcy ${ }^{61}$. Można zatem wnioskować, że w świetle „rozpraw obyczajowych” podstawowy komponent moralnego kształtowania jednostki stanowi podporządkowanie się Bożemu prawu, tj. wynikającym z niego zasadom etyki.

Pisząc o znaczeniu obrazu Boga dla wychowania moralnego w ujęciu „rozpraw obyczajowych", warto odnieść się do artykułu pt. Wychowanie dziatek, którego autor poruszył m.in. kwestię wzorców życia rodzinnego, wskazując, że relacja Jezusa z Bogiem Ojcem stanowi najlepszy model ojcostwa i synostwa. Autor ten podkreślił też, że wraz z rozwojem chrześcijaństwa wzorzec ten przyczynił się do zmiany dotychczasowych stosunków charakterystycznych dla rodzin pogańskich, w których dziecko często nie było traktowane z godnością, a nawet dopuszczano się aborcji czy porzucania potomstwa. W Wychowaniu dziatek Bóg Ojciec jawi się przede wszystkim jako wzorzec rodzica ${ }^{62}$.

W „rozprawach obyczajowych” podkreślano też wielkość Boga, a marność człowieka. Zabieg ten miał na celu wzbudzenie w odbiorcy postawy pokory, będącej przeciwieństwem ludzkiej pychy, stanowiącej mniej lub bardziej doświadczenie każdego człowieka. Podobnie jak w przypadku innych przywar, w jednym z tekstów wyjaśniono, po czym rozpoznać człowieka ulegającego pysze, oraz wskazano, że jest ona grzechem często niedostrzeganym, objawiającym się m.in. wyniosłością, poniżaniem bliźnich i nieumiejętnością przyjmowania krytyki ${ }^{63}$. W tym kontekście istotne znaczenie ma też częste przypominanie przez autorów rozpraw nauki o łasce i przeznaczeniu człowieka zgodnym z wolą Bożą. W badanych tekstach zwraca uwagę podkreślanie, że wszelkie dobra stanowią dary pochodzące od Boga, bez którego pomocy człowiek sam nie jest w stanie nic zdziałać ${ }^{4}$.

\footnotetext{
${ }^{61}$ Tamże, nr 3, 18.07.1849; tamże, nr 15, 10.10.1849; tamże, nr 18, 31.10.1849.

62 Tamże, nr 9, 29.08.1849.

${ }^{63}$ Tamże, nr 7, 15.08.1949.

${ }^{64}$ Tamże, nr 4, 25.07.1849; tamże, nr 20, 14.11.1849; tamże, nr 7, 15.08.1949.
} 


\section{Cechy wspólne „rozpraw obyczajowych”}

Wszystkie artykuły, publikowane w ramach „rozpraw obyczajowych”, zawierają kilka cech wspólnych. Rozprawy te - jak już wspomniano - w zasadniczej mierze odnoszą się do ludzkich wad, widzianych w perspektywie siedmiu grzechów głównych. Perspektywa ta stanowiła punkt wyjścia do rozważań poświęconych przywarom najczęściej dotykającym ludność polską. Oprócz odniesienia do siedmiu grzechów głównych autorzy rozpraw poruszali istotną dla kształtowania postaw moralnych problematykę społeczną, dotykając takich współczesnych im zagadnień jak laicyzacja, a nawet komunizm ${ }^{65}$.

Retoryka tekstów oscylujących wokół kwestii wychowania moralnego na łamach „Katolika” zazwyczaj jest podobna. Zwykle wpierw następuje charakterystyka określonej przywary wraz ze wskazaniem jej negatywnych skutków. Definiując poszczególne pojęcia, autorzy rozpraw zwracali też uwagę na kontekst ich funkcjonowania oraz jednostkowe intencje. Przykładowo autor artykułu poświęconego kwestii gniewu wskazywał, że może on zostać uzewnętrzniony w sposób konstruktywny (jak zrobił to Jezus, wypędzając kupców ze świątyni) bądź destrukcyjny, gdy powodowany namiętnościami i podszyty ludzkim egoizmem skutkuje krzywdą wyrządzoną drugiemu człowiekowi ${ }^{66}$. Podobnie w tekście poruszającym problematykę komunizmu zwrócono uwagę na różnice między komunizmem a występującą u chrześcijan (np. w zakonach) wspólnotowością. Wyjaśniono, że choć pozornie rzecz biorąc, pojęcia te są do siebie zbliżone, mają zupełnie inne korzenie. Komunizm (w przekonaniu jednego z autorów) wyrasta bowiem z zazdrości i wstrętu do pracy, zaś wspólnotowość chrześcijańska z ofiarności i miłości. W konsekwencji „takowa wspólność [...] nie uboży, ale bogaci, [...] nie marnuje dóbr, ale ich przysparza, [...] nie pasie próżniaka, ale zaspokaja potrzebującego" 67 .

W celu wzmocnienia przekazu autorzy rozpraw powoływali się na określone fragmenty Pisma Świętego (zwłaszcza pochodzące z Nowego Testamentu) lub odwoływali się do uznanych autorytetów (nie tylko duchownych).

Charakterystyczny element wszystkich tekstów poświęconych problematyce wychowania moralnego stanowi też odniesienie do konsekwencji grzesznego myślenia i złego postępowania. Za pomocą rozpraw próbowano wywrzeć wpływ na czytelników i uświadomić im, że grzech przynosi nie tylko skutki indywidualne, ale i społeczne. Nie ma też takiego zła, które można by ukryć przed Bogiem, gdyż życie człowieka nie kończy się z chwilą jego śmierci. W omawianych tu artykułach wielokrotnie przewija się temat wiecznego potępienia czekającego osoby, które nie postępują w sposób moralny, tj. zgodny z przykazaniami.

\footnotetext{
${ }_{65}$ Tamże, nr 9, 29.08.1849; tamże, nr 16, 17.10.1849; tamże, nr 25, 19.12.1849.

66 Tamże, nr 21, 21.11.1849.

67 Tamże, nr 16, 17.10.1849.
} 
Istotną cechą wspólną „rozpraw obyczajowych” jest także częste podkreślanie różnic między postępowaniem wedle namiętności a rozumu. Autorzy rozpraw niejednokrotnie przypominali czytelnikom o negatywnych konsekwencjach postępowania opartego na emocjach, nawoływali do wstrzemięźliwości i kierowania się przede wszystkim intelektem ${ }^{68}$. W świetle przytaczanych przez nich argumentów postępowanie według rozumu oświeconego religią pozwala na zachowanie umiarkowania cechującego osobę prawidłowo ukształtowaną pod względem etycznym.

\section{Podsumowanie}

Jak wskazują przeprowadzone analizy, treści poruszanych na łamach „Katolika Dyecezyi Chełmińskiej” "rozpraw obyczajowych” w zakresie wychowania moralnego zasadniczo korespondują z tymi, które w pierwszej połowie XIX wieku stanowiły przedmiot teologii moralnej ogólnej i szczegółowej. Znawca tematu ks. Jan Pryszmont - wskazuje, że najczęściej ówcześni teolodzy w kwestii teologii moralnej ogólnej poruszali tematy, takie jak: „czyny ludzkie i ich moralność, prawo, sumienie, cnoty, grzechy i pojednanie człowieka z Bogiem w Sakramencie Pokuty”, zaś w zakresie teologii moralnej szczegółowej: „wiara, miłość bliźniego i miłosierdzie chrześcijańskie, sprawiedliwość i wiążące się z nią zagadnienia własności, pracy i płacy oraz patriotyzmu, czystość i celibat, pokora, trzeźwość i alkoholizm, samobójstwo, kremacja i kłamstwo"69.

Istota wychowania moralnego w świetle „Katolika Dyecezyi Chełmińskiej” zasadza się zatem na myśleniu i postępowaniu zgodnym z nauczaniem Kościoła katolickiego. Celem tak pojętej moralności było przede wszystkim ukształtowanie osoby postępującej według przykazań, w bojaźni Bożej, w umiarkowaniu, przełamującej i umiejącej opanować swoje złe skłonności, kierującej się bardziej dobrem drugiego człowieka aniżeli własnym egoizmem.

„Rozprawy moralne” w zasadniczej mierze koncentrowały się wokół swoistej etyki grzechu. Już w samych ich tytułach najczęściej akcentowano ludzkie przywary, jak samolubstwo, pychę, zazdrość itd. Autorzy poszczególnych tekstów, strasząc wiecznym potępieniem, kierowali się motywacją negatywną. Takie ujęcie tematu zbieżne jest z charakterystyczną dla chrześcijaństwa tamtego okresu moralnością nakazu „przełamującego złą, bo zepsutą grzechem pierworodnym, naturę ludzką ${ }^{30}$. Etyka ta, jak wskazywał Bogdan Suchodolski, sprowadzała się do konieczności opanowywania naturalnych skłonności i opierała się na założeniu, że „życie prawdziwie godne człowieka zaczyna się tam dopiero, gdzie, $\mathrm{z}$ woli rozumu i za łaską bożą, dokonywa się wewnętrzne podniesienie na poziom

\footnotetext{
68 Tamże, nr 3, 18.07.1849; tamże, nr 21, 21.11.1849.

69 Pryszmont, Historia..., 365.

70 Bogdan Suchodolski, Wychowanie moralno-społeczne (Warszawa: Nasza Księgarnia 1947), 8.
} 
wyższy"71. Rozumowanie to stało też w sprzeczności do modnej od czasu oświecenia filozofii naturalizmu, odrzucającej charakterystyczną dla moralistów katolickich naukę o dualizmie natury ludzkiej. Dualizm ten wyraźnie wybrzmiewał bowiem w treściach analizowanych artykułów.

$\mathrm{Na}$ koniec warto podkreślić, że publikowane na łamach „Katolika Dyecezyi Chełmińskiej” „rozprawy obyczajowe” nie służyły wyłącznie wychowaniu moralnemu i kształtowaniu postaw opartych na religii. Wydaje się, że ich celem była także obrona Kościoła katolickiego przed krytyką ze strony środowisk laickich, dążących do zeświecczenia państwa (w tym szkolnictwa), a co za tym idzie pozbawienia duchownych wpływu wychowawczego na dzieci i młodzież, a w konsekwencji na kolejne pokolenia Polaków.

Streszczenie: Moralność od najdawniejszych czasów stanowi przedmiot refleksji filozofów i teologów różnych religii. Edukacja religijna jest bowiem ściśle związana z wychowaniem moralnym. Kwestie etyczne od samego początku zajmowały też istotne miejsce w nauczaniu Kościoła katolickiego. W czasach nowożytnych były one poruszane szczególnie $\mathrm{w}$ podręcznikach z zakresu teologii moralnej i dziełach spowiedniczych. Wraz z rozwojem XIX-wiecznego czasopiśmiennictwa problematykę wychowania moralnego podejmowano też na łamach polskich gazet. Jedną z nich był wydawany w Prusach Zachodnich w latach 1849-1851 „Katolik Dyecezyi Chełmińskiej”, na którego łamach publikowano m.in. „rozprawy obyczajowe”, służące szerzeniu postaw i zachowań moralnych zgodnie z nauczaniem Kościoła katolickiego. Celem niniejszego artykułu jest (re)konstrukcja wychowania moralnego w świetle wspomnianych rozpraw, a także wyjaśnienie: do kogo były one kierowane, czemu miały służyć oraz jakie idee moralne próbowano za ich pomocą rozszerzać.

Słowa kluczowe: wychowanie moralne, etyka, teologia moralna, prasa polska, Prusy Zachodnie

\section{Bibliografia}

Banach, Jacek. Prasa polska Prus Zachodnich w latach 1848-1914. Gdańsk: Wydawnictwo Uniwersytetu Gdańskiego, 1999.

Bukowski, Andrzej. „Gółkowski Józef Szczepan”. W: Słownik biograficzny Pomorza Nadwiślańskiego, t. 2: G-K, red. Zbigniew Nowak. Gdańsk: Wydawnictwo Gdańskie, 1994.

Cieślak, Tadeusz. Prasa Pomorza Wschodniego w XIX i XX wieku. Warszawa: Państwowe Wydawnictwo Naukowe, 1966.

Greniuk, Franciszek. Katolicka teologia moralna w poszukiwaniu własnej tożsamości. Lublin: Redakcja Wydawnictw Katolickiego Uniwersytetu Lubelskiego, 1993.

71 Tamże. 
Greniuk, Franciszek. „Teologia moralna w XIX wieku”. W: Dzieje teologii katolickiej w Polsce, t. 3: Wiek XIX i XX, cz. 1, red. Marian Rechowicz. Lublin: Wydawnictwo Towarzystwa Naukowego Katolickiego Uniwersytetu Lubelskiego, 1976.

Jasionek, Stanisław. Wychowanie moralne. Kraków: WSF-P Ignatianum, Wydawnictwo WAM, 2004.

„Katolik Dyecezyi Chełmińskiej”: nr 1, 1.07.1849; nr 3, 18.07.1849; nr 4, 25.07.1849; nr 7, 15.08.1849; nr 9, 29.08.1849; nr 11, 12.09.1849; nr 15, 10.10.1849; nr 16, 17.10.1849; nr 18, 31.10.1849; nr 19, 7.11.1849; nr 20, 14.11.1849; nr 21, 21.11.1849; nr 24, 12.12.1849; nr 25, 19.12.1849; nr 1, 2.01.1850; nr 5, 30.01.1850; nr 6, 6.02.1850; nr 11, 13.03.1850; nr 22, 29.05.1850; nr 23, 5.06.1850; nr 24, 12.06.1850; nr 25, 19.06.1850; nr 26, 26.06.1850; nr 1, 1.01.1851.

Łobocki, Mieczysław. Wychowanie moralne w zarysie. Kraków: Oficyna Wydawnicza „Impuls”, 2009.

Mross, Henryk. „Osmański Mateusz”. W: Słownik biograficzny Pomorza Nadwiślańskiego, red. Stanisław Gierszewski, t. 3: $L-P$, red. Zbigniew Nowak. Gdańsk: Wydawnictwo Gdańskie, 1997.

Mrozek, Zdzisław. „Pokojski Adam”. W: Słownik biograficzny Pomorza Nadwiślańskiego, red. Stanisław Gierszewski, t. 3: $L-P$, red. Zbigniew Nowak. Gdańsk: Wydawnictwo Gdańskie, 1997.

Nadolny, Anastazy. „Kręcki Kazimierz”. W: Słownik biograficzny Pomorza Nadwiślańskiego, t. 2: G-K, red. Zbigniew Nowak. Gdańsk: Wydawnictwo Gdańskie, 1994.

Pinckaers, Servais Théodore. Źródła moralności chrześcijańskiej. Jej metoda, treść, historia. Poznań: W Drodze, 1994.

Pryszmont, Jan. Historia teologii moralnej. Warszawa: Akademia Teologii Katolickiej, 1987.

Romanow, Andrzej. „Pielgrzym” pelpliński w latach 1869-1920. Gdańsk-Pelplin: Instytut Kaszubski, 2007.

Romanow, Andrzej. „Prasa jako źródło do dziejów Pomorza XIX wieku”. W: Prasa regionalna jako źródło do badań historycznych okresu XIX i XX wieku, red. Joanna Nowosielska-Sobel, Grzegorz Strauchold, Tomasz Ślepowroński. Wrocław: ATUT, 2011.

Suchodolski, Bogdan. Wychowanie moralno-społeczne. Warszawa: Nasza Księgarnia, 1947.

Wierzchosławski, Szczepan. „Od upadku Polski do odzyskania niepodległości (17951920)". W: Dzieje Chetmna. Zarys monograficzny, red. Marian. Biskup. Warszawa-Poznań-Toruń: Państwowe Wydawnictwo Naukowe, 1987. 